\title{
PENGARUH KOMPOS TANDAN KOSONG KELAPA SAWIT TERHADAP PERTUMBUHAN DAN HASIL LOBAK PADA TANAH ALUVIAL
}

\author{
EFFECT OF EMPTY FRUIT BUNCHES OF OIL PALM COMPOST ON GROWTH AND \\ YIELD OF RADISH ON ALLUVIAL SOIL
}

Agnes Santi, Tri Rahayuni dan Eddy Santoso

Program Studi Agroteknologi Fakultas Pertanian Universitas Tanjungpura, Pontianak Jln. Prof. Dr. Hadari Nawawi, Pontianak, 78124, Indonesia.

Email agnes.santi@gmail.com

\begin{abstract}
ABSTRAK
Penelitian ini bertujuan untuk mengetahui pengaruh kompos tandan kosong kelapa sawit terhadap pertumbuhan dan hasil lobak pada tanah aluvial. Penelitian dilaksanakan dikebun percobaan Fakultas Pertanian Universitas Tanjungpura, dilaksanakan pada tanggal 15 April 2014 sampai dengan tanggal 29 Mei 2014. Penelitian ini menggunakan Rancangan Acak Lengkap (RAL) yang terdiri dari 5 perlakuan dan 4 ulangan, setiap ulangan terdiri dari 4 sampel tanaman jadi terdapat 80 polibag tanaman. Perlakuan yang dimaksud adalah $\mathrm{t} 1=5 \%$ bahan organik, $\mathrm{t} 2=10 \%$ bahan organik, $\mathrm{t} 3=15 \%$ bahan organik, $\mathrm{t} 4=20 \%$ bahan organik, $\mathrm{t} 5=25 \%$ bahan organik. Variabel yang diamati dalam penelitian ini adalah jumlah daun (helai), berat basah bagian atas tanaman (g), berat basah umbi tanaman $(\mathrm{g})$, panjang umbi tanaman $(\mathrm{cm})$, diameter umbi tanaman $(\mathrm{cm})$. Hasil penelitian menunjukkan bahwa pemberian kompos tandan kosong kelapa sawit, berpengaruh nyata terhadap variabel pengamatan jumlah daun pada minggu ke-4, ke-6, berat basah bagian atas tanaman, berat basah umbi pertanaman, panjang umbi pertanaman, dan diameter umbi pertanaman. Tetapi pemberian kompos tandan kosong kelapa sawit berpengaruh tidak nyata terhadap variabel pengamatan jumlah daun pada minggu ke-2. Pemberian $20 \%$ bahan organik memberikan pertumbuhan dan hasil lobak yang terbaik.
\end{abstract}

Kata kunci : Aluvial, kompos tandan kosong kelapa sawit, lobak.

\section{ABSTRACT}

This study aims to determine the effect of empty fruit bunches of oil palm compost on growth and yield of radish on alluvial soil. Research conducted at the experimental farm of the Faculty of Agriculture, University of Tanjungpura, was conducted April 15, 2014 through the date of May 29, 2014. This study used a completely randomized design (CRD), which consists of the 5 treatments and 4 replications, each replication consisted of four samples of the plants are 80 polybags. The treatment in question is $t 1=5 \%$ of organic matter, $t 2=10 \%$ of organic matter, $t 3=15 \%$ of organic matter, $t 4=$ $20 \%$ of organic matter, $t 5=25 \%$ of organic matter. The variables measured in this study is the number of leaves (pieces), the top of the plant fresh weight $(\mathrm{g})$, tuber fresh weight of plant ( $\mathrm{g}$ ), length of tuber crops $(\mathrm{cm})$, diameter of the tuber crop $(\mathrm{cm})$. The results showed that the composting of oil palm empty fruit bunches, observation variables significantly affect the number of leaves on the 4th week, 6th, wet weight of the upper part of plant, fresh weight of tuber crops, tuber crops length and diameter of the tuber crop, but composting of oil palm empty fruit bunches no real effect on the observation variable number of leaves on the 2 nd week. $20 \%$ of organic matter deliver growth and yield of best radish.

Keywords: Alluvial, composts empty fruit bunches of oil palm, radish. 


\section{PENDAHULUAN}

Lobak merupakan salah satu tanaman hortikultura yang cukup penting ditinjau dari segi ekonomi dan kandungan gizinya. Hampir seluruh bagian lobak dapat dimanfaatkan untuk berbagai keperluan kehidupan manusia. Di India dan Cina, biji lobak digunakan untuk obat masuk angin serta memperlancar buang air kecil. Perusahaan kosmetik banyak menggunakan lobak untuk dijadikan shampo, masker dan campuran kosmetik lainnya, (Saparinto, 2012). Bertambahnya penduduk dan pendapatan yang semakin meningkat, menyebabkan permintaan pasar dalam negeri terhadap berbagai jenis produk pangan cenderung terus meningkat, termasuk lobak cenderung terus meningkat, oleh karena itu tanaman lobak yang sudah mulai dikenali masyarakat terus ditingkatkan pembudidayaannya.

Produksi lobak di Kalimantan Barat mencapai 868 ton dengan luas areal 289 ha atau rata-rata produksi 3,0 ton/ha dan pada tahun 2011 produksi lobak mengalami peningkatan 924 ton dengan luas areal 272 ha atau rata-rata produksinya 3,24 ton /ha. Produksi tanaman lobak di Kalimantan Barat masih rendah apabila dibandingkan dengan produksi lobak nasional, pada tahun 2011 mencapai 27,279 ton/ha (Badan Pusat Statistik,2011).

Salah satu jenis tanah yang dapat dimanfaatkan untuk membudidayakan lobak adalah tanah aluvial. Tanah aluvial merupakan tanah yang cukup potensial untuk pengembangan tanaman lobak namun tanah aluvial kurang mendukung untuk pertumbuhan dan hasil produksi tanaman yang maksimal. Hal ini disebabkan karena adanya faktor pembatas antara lain sifat fisik, kimia, dan biologi tanah aluvial itu sendiri yang memiliki tekstur tanah dengan kandungan liat 53,40\% dan pada strukturnya sendiri adalah tanpa struktur dengan konsistensinya yang keras diwaktu kering dan teguh pada kondisi lembab, drainase buruk sampai sedang, bahan organik rendah dan $\mathrm{pH}$ rendah. Berdasarkan sifat fisik, kimia, dan biologi tanah yang kurang menguntungkan bagi tanaman, dapat menghambat proses pembentukan umbi di dalam tanah.
Kompos Tandan Kosong Kelapa Sawit (TKKS) mengandung C-organik sebesar $16,84 \%$, Nitrogen $1,56 \%, \mathrm{C} / \mathrm{N}$ ratio $10,79 \%$, fosfor $1,25 \%$, kalium $0,94 \%$ (Laboratorium Kimia dan Kesuburan Tanah, 2013). Kompos TKKS memiliki beberapa sifat yang menguntungkan antara lain : Memperbaiki struktur tanah berlempung menjadi ringan, membantu kelarutan unsur-unsur hara yang diperlukan bagi pertumbuhan tanaman, bersifat homogen dan mengurangi resiko sebagai pembawa hama tanaman, merupakan pupuk yang tidak mudah tercuci oleh air yang meresap ke dalam tanah dan dapat diaplikasikan pada sembarang musim.

\section{METODE PENELITIAN}

Penelitian ini dilaksanakan di kebun percobaan Fakultas Pertanian Universitas Tanjungpura Pontianak dan waktu penelitian selama 45 hari (15 April - 29 Mei 2014). Rancangan Percobaan yang digunakan dalam penelitian ini adalah Rancangan Acak Lengkap (RAL) 1 faktor, yaitu kompos TKKS, dengan 5 taraf perlakuan yang diulang sebanyak 4 kali, setiap ulangan terdiri dari 4 sampel sehingga tanaman seluruhnya berjumlah 80 tanaman. Perlakuan yang dimaksud adalah :

$\mathrm{t}_{1}=5 \%$ bahan organik dalam tanah atau setara dengan $550 \mathrm{~g} /$ polibag kompos tandan kosong kelapa sawit

$t_{2}=10 \%$ bahan organik dalam tanah atau setara dengan $1600 \mathrm{~g} /$ polibag kompos tandan kosong kelapa sawit

$\mathrm{t}_{3}=15 \%$ bahan organik dalam tanah atau setara dengan 2620 g/polibag kompos tandan kosong kelapa sawit.

$\mathrm{t}_{4}=20 \%$ bahan organik dalam tanah atau setara dengan $3650 \mathrm{~g} /$ polibag kompos tandan kosong kelapa sawit

$\mathrm{t}_{5}=25 \%$ bahan organik dalam tanah atau setara dengan $4700 \mathrm{~g} /$ polibag kompos tandan kosong kelapa sawit

\section{HASIL DAN PEMBAHASAN}

Hasil

Hasil analisis keragaman pengaruh dosis dan kompos TKKS terhadap variabel jumlah daun, berat basah bagian atas tanaman, berat basah umbi pertanaman, panjang umbi pertanaman dan diameter umbi pertanaman, yang diamati disajikan pada Tabel 1 . 
Tabel 1. Rekapitulasi Hasil Penelitian Dari Pengaruh Pemberian Kompos TKKS Terhadap Beberapa Variabel Pengamatan.

\begin{tabular}{|c|c|c|c|c|c|c|c|}
\hline \multirow{3}{*}{$\begin{array}{l}\text { Bahan } \\
\text { Organik (\%) }\end{array}$} & \multicolumn{7}{|c|}{ Variabel } \\
\hline & \multicolumn{3}{|c|}{ JDMinggu ke- } & \multirow{2}{*}{ BBBAT } & \multirow[t]{2}{*}{ BBUP } & \multirow[t]{2}{*}{ PUP } & \multirow[t]{2}{*}{ DUP } \\
\hline & 2 & 4 & 6 & & & & \\
\hline $5 \%$ & 4,18 & $9,5 \mathrm{a}$ & $9,19 \mathrm{a}$ & $29,87 \mathrm{a}$ & $14,77 \mathrm{a}$ & $7,07 \mathrm{a}$ & $0,71 \mathrm{a}$ \\
\hline $10 \%$ & 5,68 & $14,19 \mathrm{~b}$ & $11,44 \mathrm{ab}$ & $67,42 \mathrm{~b}$ & $67,48 \mathrm{ab}$ & $14,35 \mathrm{~b}$ & $2,96 \mathrm{~b}$ \\
\hline $15 \%$ & 5,68 & $14,44 \mathrm{~b}$ & $13,5 \mathrm{ab}$ & $65,69 \mathrm{~b}$ & $87,1 \mathrm{bc}$ & $15,62 \mathrm{bc}$ & $3,07 \mathrm{~b}$ \\
\hline $20 \%$ & 4,6 & $15,38 \mathrm{~b}$ & $15,12 \mathrm{~b}$ & $68,24 \mathrm{~b}$ & $135,62 \mathrm{~cd}$ & $19,61 \mathrm{~cd}$ & $3,31 \mathrm{~b}$ \\
\hline $25 \%$ & 7,25 & $17 \mathrm{~b}$ & $14,87 \mathrm{~b}$ & $71,8 \mathrm{~b}$ & $176,78 \mathrm{~d}$ & $22,3 \mathrm{~d}$ & $3,48 \mathrm{~b}$ \\
\hline F hit & 0,99 & 8,12 & 6,16 & 6,75 & 21,76 & 32,18 & 39,81 \\
\hline KK (\%) & $43,36 \%$ & $13,91 \%$ & $15,73 \%$ & $21,29 \%$ & $27,77 \%$ & $12,98 \%$ & $13,28 \%$ \\
\hline BNJ 5\% & - & $4,29 \%$ & $4,41 \%$ & $29,13 \%$ & $58,47 \%$ & $4,48 \%$ & 0,79 \\
\hline $\mathrm{F}$ tab & & & & 3,05 & & & \\
\hline
\end{tabular}

Sumber : Hasil analisis data 2014

Keterangan : JD $=$ jumlah daun, BBBAT $=$ berat basah bagian atas tanaman, $\mathrm{BBUP}=$ berat basah umbi pertanaman, $\mathrm{PUP}=$ panjang umbi pertanaman, $\mathrm{DUP}=$ diameter umbi peranaman.

Kompos dapat memperbaiki kualitas tanah, ketersediaan bahan organik di dalam tanah ikut menentukan kesuburan tanah sebab bahan organik di dalam tanah berfungsi sebagai unsur hara, merangsang aktivitas mikroorganisme tanah, dan memperbaiki sifat fisika, kimia dan biologi tanah. Menurut Djuarnani, Kristian dan Setiawan (2005) pada sifat fisik, kompos memperbaiki struktur tanah aluvial sehingga membentuk agregat tanah yang lebih baik dan memantapkan agregat yang telah terbentuk sehingga akan memperbaiki pula aerasi, drainase, absorbsi panas, kemampuan daya serap tanah terhadap air serta berguna untuk mengendalikan penggenangan air pada tanah aluvial.

Sifat biologi tanah meningkatkan populasi dan mikroorganisme tanah dan dari hasil aktivitas mikrobia pula akan terlepas berbagai zat pengatur tumbuh (auxin) dan vitamin yang akan berdampak positif bagi pertumbuhan tanaman.

Pengaruh kompos terhadap sifat kimia tanah antara lain kapasitas pertukaran kation, kapasitas pertukaran anion, $\mathrm{pH}$ tanah, daya sangga tanah dan terhadap keharaan tanah. Kapasitas pertukaran kation (KPK) menunjukkan kemampuan tanah untuk menahan kation-kation dan mempertukarkan kation-kation tersebut termasuk kation hara tanaman, penambahan kompos pada tanah aluvial mampu meningkatkan $\mathrm{pH}$ tanah.

Perhitungan jumlah daun dilakukan pada seluruh tanaman sampel dan dilakukan setiap 2 minggu sekali, mulai dari minggu ke-2 setelah tanam sampai minggu ke-6. Daun yang dihitung adalah daun yang telah membuka sempurna. Pada Tabel 1, diketahui bahwa pemberian kompos TKKS berpengaruh tidak nyata terhadap jumlah daun pada minggu ke-2 dan berpengaruh nyata terhadap jumlah daun pada minggu ke-4 dan ke-6.

Faktor dalam (faktor genetik) merupakan faktor yang mempengaruhi suatu variabel pengamatan berpengaruh tidak nyata dan faktor luar seperti ketersediaan air, unsur hara, iklim dan tanah, serta perkembangan hama dan penyakit. Menurut William (1993) faktor genetik adalah suatu faktor yang menentukan batas pertumbuhan tiap sel organ dan seluruh bagian daun sehingga kadangkadang pada waktu tertentu jumlah daun tidak akan bertambah.

Pemberian perlakuan kompos TKKS pada Tabel 1, berpengaruh tidak nyata terhadap jumlah daun minggu ke-2 dan berpengaruh nyata terhadap jumlah daun minggu ke-4 dan ke-6. Berpengaruh tidak nyatanya jumlah daun minggu kedua disebabkan tanaman lobak baru saja dipindahkan dari media persemaian ke media tanam, sehingga tanaman lobak membutuhkan waktu untuk beradaptasi dengan lingkungan yang baru, sehingga peningkatan jumlah daun belum begitu terlihat. Perlakuan kompos TKKS terhadap lobak umur 4 MST menghasilkan 17 helai daun, sedangkan pada lobak umur 6 MST menghasilkan 14,87 helai 
daun. Penurunan jumlah daun ini disebabkan karena serangan hama ulat Plutela xylostella yang terjadi pada minggu ke-4 sampai minggu ke-5, mengakibatkan daun busuk, mati dan gugur. Perkembangan pembentukan umbi menjadi kurang baik, hasil dari fotosintesis tidak maksimal sehingga hasil yang disalurkan ke umbi menjadi berkurang. Menurut Sutedjo dan Kartasapoetra (1988) bahwa laju fotosintesis yang tinggi menyebabkan karbohidrat yang dihasilkan tanaman menjadi lebih banyak dimana dengan meningkatnya fotosintat akan mempengaruhi penumpukan bahan organik di dalam tubuh tanaman itu sendiri.

Jumlah daun merupakan salah satu indikator pertumbuhan dan perkembangan tanaman. Pertumbuhan tanaman dimulai dengan terjadinya pembelahan sel hingga bertambah besarnya protoplasma yang berakibat berkembangnya suatu jaringan, menyebabkan ukuran tanaman bertambah (Hardjadi, 1983). Menurut Sarief (1986) unsur hara merupakan faktor yang menentukan pertumbuhan tanaman. Pertumbuhan tanaman yang optimal memerlukan unsur hara yang seimbang dengan jumlah yang dibutuhkan tanaman. Penambahan jumlah daun berhubungan dengan aktifitas sel-sel meristimatik di titik tumbuh, yang terjadi akibat pembelahan sel meristem apikal pada kuncup terminal dan kuncup lateral yang menghasilkan sel-sel baru dan akan menumbuhkan daun (Kimball, 1990). Pertumbuhan juga didukung oleh ketersediaan unsur-unsur hara antara lain Nitrogen $(\mathrm{K})$, Phospor (P) dan Kalium (K) (Indranada, 1986).

Pengamatan berat basah bagian atas tanaman dilakukan pada saat panen dan dapat dilihat pada Tabel 1, diketahui bahwa setiap pemberian perlakuan kompos TKKS berpengaruh nyata terhadap berat basah bagian atas tanaman lobak. Daun merupakan organ utama tanaman karena proses fotosintesis tanaman berlangsung pada daun. Pemberian kompos TKKS memperbaiki sifat fisik tanah sehingga perkembangan perakaran menjadi lebih baik dan dapat mengabsorbsi unsur hara dan penyerapan air sehingga memungkinkan proses fotosintesis berlangsung dengan baik.

Pengamatan berat basah umbi pertanaman dilakukan pada saat panen dan rerata hasil pengamatan dapat dilihat pada Tabel 1 terlihat bahwa setiap pemberian perlakuan berpengaruh nyata terhadap berat basah umbi pertanaman lobak. Berat basah umbi lobak pertanaman meningkat seiring dengan peningkatan dosis kompos TKKS yang diberikan. Salah satu kandungan unsur hara utama kompos TKKS adalah Kalium (K).

Menurut Wargiono (1989) K berperan dalam pembentukan karbohidrat, dan dengan meningkatnya karbohidrat yang dihasilkan juga meningkatkan hasil umbi salah satunya penambahan bobot segar umbi. Unsur hara yang tersedia optimum pada suatu tanaman, akan saling mendukung dalam proses fotosintesis, sehingga tanaman dapat menghasilkan umbi lobak yang lebih berat dan berkualitas. Semakin banyak hasil fotosintesis maka semakin banyak pula yang dikirimkan keseluruh keperluan pertumbuhan tanaman lainnya (Jumin, 2002). Kompos TKKS meningkatkan $\mathrm{pH}$ tanah yang tadinya 4,26 menjadi 6-6,7 sehingga $\mathrm{pH}$ tanah menjadi sesuai dengan kebutuhan pertumbuhan tanaman lobak. Jika $\mathrm{pH}$ tanah rendah pembentukan umbi menjadi terhambat. Sebaliknya, jika $\mathrm{Ph}$ tanah terlalu tinggi (tanah bersifat sangat basa), tanaman akan mengalami gejala kekurangan unsur kalium (Cahyono, 2000). pH tanah yang sesuai membuat unsur hara tidak terikat sehingga bisa diserap oleh tanaman lobak dengan baik,

Pengamatan panjang umbi pertanaman dan diameter umbi dilakukan pada saat panen dan pada Tabel 1 terlihat bahwa setiap pemberian perlakuan berpengaruh nyata terhadap panjang umbi dan diameter pertanaman lobak. Pemberian kompos TKKS pada tanah aluvial membuat $\mathrm{pH}$ tanah menjadi baik dan unsur hara menjadi tersedia bagi tanaman lobak sehingga dapat diserap oleh akar untuk proses fotosintesis yang kemudian hasil dari fotosintesis dikirimkan keumbi sebagai cadangan makanan. Pada sifat fisik pemberian kompos TKKS membuat tanah menjadi baik, gembur, aerasi tanah baik karena kandungan oksigen dalam tanah cukup dan respirasi akar berlangsung baik sehingga akar berkembang dengan cepat. Sifat fisik tanah yang baik akan menjamin serapan hara $\mathrm{N}, \mathrm{P}, \mathrm{K}$ dan unsur-unsur lainnya berlangsung baik. Perkembangan sistem perakaran tanaman memerlukan unsur $\mathrm{N}$ dan $\mathrm{P}$ yang merupakan 
bagian dari inti sel. Unsur tersebut sangat penting dalam pembelahan sel dan perkembangan jaringan meristematik, sedangkan $\mathrm{K}$ berperan dalam membantu pembentukan karbohidrat (Sutedjo, 2010).

Fungsi $\mathrm{P}$ (fosfor) adalah memberikan energi tinggi bagi tanaman dalam proses asimilasi dan respirasi. Unsur $\mathrm{P}$ (fosfor), mendorong pembentukan perakaran tanaman dan meningkatkan daya absorbsi hara dalam tanah. Pertumbuhan dan perkembangan akar yang sempurna membutuhkan penyerapan air dan hara yang optimal sehingga menghasilkan umbi yang baik (Lakitan, 2001). Menurut Djuarnani, Kristian dan Setiawan (2005) pemberian kompos pada tanah akan membantu melonggarkan partikel tanah yang padat dengan cara membuka pori-pori tanah yang merupakan saluran atau jalan bagi udara dan air.

Hasil dari penelitian pemberian kompos tandan kosong kelapa sawit pada tanah aluvial menunjukkan hasil umbi lobak pada penelitian ini masih jauh dibandingkan hasil umbi lobak pada deskripsi, hasil rerata selama penelitian menunjukkan panjang $15,79 \mathrm{~cm}$, diameter 2,71 $\mathrm{cm}$, berat $96,35 \mathrm{~g}$, sedangkan pada deskripsi panjang $\pm 35 \mathrm{~cm}$, diameter $5,9 \mathrm{~cm}$, berat $400 \mathrm{~g}$.

Hama yang menyerang pada penelitian ini adalah belalang, dan ulat Plutela xylostella. Pengendalian hama digunakan insektisida matador dan campuran air tembakau dan bawang putih.

Hipotesis yang diajukan dalam penelitian ini adalah diduga pemberian $15 \%$ bahan organik, memberikan pengaruh terbaik terhadap pertumbuhan dan hasil tanaman lobak di tanah aluvial. Hasil yang diperoleh selama penelitian ternyata pemberian $20 \%$ bahan organik memberikan hasil yang terbaik dari variabel pengamatan dengan demikian hipotesis yang diajukan dalam penelitian ini ditolak.

\section{SIMPULAN}

Berdasarkan hasil penelitian pengaruh kompos TKKS terhadap hasil tanaman lobak di tanah aluvial dapat disimpulkan bahwa :

1. Pemberian kompos TKKS dapat meningkatkan hasil tanaman lobak pada tanah aluvial.

2. Pemberian kompos TKKS dengan dosis $3650 \mathrm{~g} /$ polibag atau setara dengan $20 \%$ bahan organik memberikan hasil rerata terbaik pada berat basah umbi pertanaman sebesar 135,62 g

\section{DAFTAR PUSTAKA}

Biro Pusat Statistik. 2011. Statistik Tanaman Sayuran dan Buah-buahan Semusim Kalimantan Barat. Kantor Statistik. Pontianak.

Cahyono, B. dan D. Juanda. 2000. Ubi Jalar, Budidaya dan Analisis Usaha Tani. Kanisius. Yogyakarta.

Djuarnani, N. Kristian, dan B.S. Setiawan. 2005. Cara Cepat Membuat Kompos. Agro Media Pustaka. Depok.

Hardjadi, S.S. 1983. Pengantar Agronomi. Gramedia. Jakarta.

Hardjowigeno, S. 2010. Ilmu Tanah. Mediatama Sarana Perkasa. Jakarta.

Indradana, K.H. 1986. Pengelolaan Kesuburan Tanah. Bina Aksara. Jakarta.

Jumin, H. B. 2002. Agroekologi, Suatu Pendekatan Fisiologis. Raja Grafindo Persada. Jakarta.

Kimball, J.W. 1990. Biologi. Terjemahan Siti Sutarni T Dan Sugimin. Erlangga. Jakarta.

Lakitan, B. 2001. Dasar - Dasar Fisiologi Tanaman. Raja Grafindo Persada. Jakarta

Saparinto, C. dan H.D. Setyaningrum. 2012. Panen Sayur Secara Rutin di Lahan Sempit. Penebar Swadaya. Jakarta.

Sarief, E. S. 1986. Ilmu Tanah Pertanian. Pustaka Buana. Bandung.

Sutedjo, M. M. 2010. Pupuk dan Cara Pemupukan. Rineka Cipta. Jakarta.

Sutedjo, M. M., dan A. G. Kartasapoetra. 1988. Pengantar Ilmu Tanah, Terbentuknya Tanah dan Tanah Pertanian. Bina Aksara. Jakarta

Wargiono, J. 1989. Budidaya Ubi Jalar. Bharata. Jakarta Sutedjo, M. M. 2010. Pupuk dan Cara Pemupukan. Rineka Cipta. Jakarta.

William, CN., J.O Uzo dan W.T.H. Peregrine, 1993, Produksi Tanaman Daerah Tropika, Terjemahan Soedharoedjian R, Gadjah Mada University Press, Yogyakarta. 